\title{
A late Caledonian tectono-thermal event in the Gaissa Nappe Complex, Arctic Norway: evidence from fine-fraction K-Ar dating and illite crystallinity from the Digermulen Peninsula
}

Guido Meinhold $^{\mathrm{a}, \mathrm{b}}$, Klaus Wemmer ${ }^{\mathrm{b}}$, Anette E. S. Högström ${ }^{\mathrm{c}}$, Jan Ove R. Ebbestad ${ }^{\mathrm{d}}$, Sören Jensen $^{\mathrm{e}}$, Teodoro Palacios ${ }^{\mathrm{e}}$, Magne Høyberget ${ }^{\mathrm{f}}$, Heda Agić ${ }^{\mathrm{g}}$ and Wendy L. Taylor ${ }^{\mathrm{h}}$

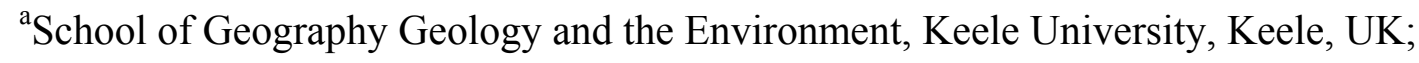

${ }^{\mathrm{b}}$ Geowissenschaftliches Zentrum Göttingen, Universität Göttingen, Göttingen, Germany;

${ }^{\mathrm{c}}$ Tromsø University Museum, UiT - The Arctic University of Norway, Tromsø, Norway;

${ }^{\mathrm{d}}$ Museum of Evolution, Uppsala University, Uppsala, Sweden;

eÁrea de Paleontología, Universidad de Extremadura, Badajoz, Spain;

${ }^{\mathrm{f}}$ Rennesveien 14, Mandal, Norway;

${ }^{\mathrm{g}}$ Department of Earth Science, University of California, Santa Barbara, USA;

${ }^{\mathrm{h}}$ Department of Geological Sciences, University of Cape Town, Rondebosch, South Africa

\begin{abstract}
Fine-fraction $\mathrm{K}-\mathrm{Ar}$ dating and illite crystallinity determination were applied on a peculiar pale olive green shale sample from the upper Ediacaran Indreelva Member (Stáhpogieddi Formation, Vestertana Group, Gaissa Nappe Complex) of the Digermulen Peninsula in Finnmark, Arctic Norway, to constrain the age and metamorphic conditions of tectonothermal overprint. The $<2 \mu \mathrm{m}$ and $<0.2 \mu \mathrm{m}$ grain-size fractions are almost purely illite and yielded an illite crystallinity (expressed as the Kübler index) of $0.215 \Delta^{\circ} 2 \theta$ and $0.228 \Delta^{\circ} 2 \theta$ and $\mathrm{K}-\mathrm{Ar}$ ages of $403.9 \pm 4.2 \mathrm{Ma}$ and $391.5 \pm 4.0 \mathrm{Ma}$, respectively. The $\mathrm{K}-\mathrm{Ar}$ ages are interpreted to present late-stage thermal overprint under low epizonal conditions along a localised shear zone, likely post-dating the peak of metamorphism and cleavage generation on the Digermulen Peninsula. Thus, a later tectono-metamorphic event related to the late stage of the Scandian orogeny is locally recorded in the Gaissa Nappe Complex of the Caledonides of Finnmark. This late Scandian event was probably caused by orogenic extensional collapse and appears to have extended at least into Mid-Devonian time.
\end{abstract}

\section{Keywords}

Caledonides; Scandian orogeny; Finnmark; K-Ar geochronology; Ediacaran; Devonian 


\section{Introduction}

The Caledonides in Finnmark, Arctic Norway, mainly comprise the Lower and Middle Allochthons of the Scandinavian Caledonides (Gee et al. 1985; Roberts 1985; Gayer et al. 1987). The Lower Allochthon is represented solely by the Gaissa Nappe Complex (Rosendahl 1945; Sturt et al. 1975; Roberts 1985; Sundvoll \& Roberts 2003; Fig. 1A), which is also termed informally the Gaissa Thrust Belt (Townsend et al. 1986), and is essentially a series of westerly dipping imbricate foreland thrust sheets, composed dominantly of Neoproterozoic to Lower Ordovician fluvial and shallow-marine sediments (Townsend et al. 1986; Gayer et al. 1987). Metamorphic grade reached middle-upper anchizone/sub-greenschist facies conditions (Townsend et al. 1986; Dallmeyer et al. 1989). Geochronological dates on the timing of metamorphism in the Gaissa Nappe Complex are ambivalent, ranging from Cambrian to Devonian (Pringle 1973; Sturt et al. 1975; Dallmeyer 1988; Dallmeyer et al. 1989; Sundvoll $\&$ Roberts 2003). These ages are commonly assigned to the Finnmarkian Orogeny (c. 520$480 \mathrm{Ma}$ ) and the Scandian Orogeny (c. 430-380 Ma) and both are seen as tectonic phases of the Caledonian Orogeny. However, the concept of a Finnmarkian Orogeny (e.g. Sturt et al. 1978) has to be questioned, as demonstrated by modern geochronological studies (e.g. Kirkland et al. 2008; Corfu et al. 2011, 2014).

Metamorphic ages of the Gaissa Nappe Complex are available mainly from the mainland of Finnmark and the Varanger Peninsula (Pringle 1973; Sturt et al. 1975; Dallmeyer 1988; Dallmeyer et al. 1989; Sundvoll \& Roberts 2003). No metamorphic ages were previously available from the Digermulen Peninsula (Fig. 1A). Here we present the first finefraction $\mathrm{K}-\mathrm{Ar}$ ages and illite crystallinity from the Digermulen Peninsula and discuss their implications for Caledonian tectono-metamorphism in the Gaissa Nappe Complex.

\section{Regional geology}

The Gaissa Nappe Complex solely represents the Lower Allochthon of the Caledonides of Finnmark (Fig. 1A). It preserves a Cryogenian to lowermost Ordovician approximately $3 \mathrm{~km}$ thick succession of essentially siliciclastic sedimentary rocks, assigned to the Vestertana and Digermulen groups (Reading 1965; Banks et al. 1971; Rice 2014). This succession is well exposed in the Tanafjorden-Varangerfjorden region, for example, on the Digermulen Peninsula (Fig. 1A-C). Here, the Ediacaran succession of the Vestertana Group, i.e. the Stáhpogieddi Formation, has received much attention in recent years as it contains the only 
Ediacara-type fossils in Scandinavia (Farmer et al. 1992; Högström et al. 2013, 2017; Jensen et al. 2018a, b; Fig. 1B). The Stáhpogieddi Formation comprises the Lillevannet, Indreelva and Manndrapselva members, which are made up mainly of shale, siltstone and sandstone deposited in a marine environment (Reading 1965; Banks et al. 1971; Fig. 1B). Slaty cleavage cuts bedding at a low angle and dips toward the NW. The sedimentary package experienced a very low-grade thermal overprint so that most of the (primary and secondary) sedimentary features are well preserved. The colour of the organic-walled microfossils from the Manndrapselva Member of the Stáhpogieddi Formation suggests a post-mature level, indicating a thermal overprint of 200 to $250^{\circ} \mathrm{C}$ (T. Palacios, unpublished data). The timing of deformation and metamorphic overprint, including the cleavage formation, is commonly assigned to the continent-continent collision between Laurentia and Baltica, leading to the formation of the Caledonides, during Silurian to Devonian times (Fig. 1D). Geochronological constraints on the tectono-metamorphic overprint of the low-grade metasedimentary succession of the Digermulen Peninsula are however lacking.

\section{Sample description and methods}

Approximately $2 \mathrm{~kg}$ of a $15 \mathrm{~cm}$ thick bed of pale olive green shale (sample D14-G7, which corresponds to the specimens TSGF 18418 and TSGF 18419 catalogued in the geological collections at the Tromsø University Museum) from the upper Ediacaran Indreelva Member (Stáhpogieddi Formation, Vestertana Group) of the Digermulen Peninsula was collected from outcrop (geographic coordinates: $70^{\circ} 34^{\prime} 45.6 \mathrm{~N}, 28^{\circ} 08^{\prime} 42.9 \mathrm{E}$ ), approximately $10.5 \mathrm{~m}$ below the top of the Indreelva Member along a section to the west of the Manndrapselva river mouth (Figs. 1A-C). During fieldwork this shale was thought to be a K-bentonite. Further studies however, could neither confirm nor reject this interpretation. Alternatively, the shale could have been thermally altered along a shear zone which led to its peculiar appearance (Fig. 2A). The sample was prepared for follow-up analyses at the Geowissenschaftliches Zentrum Göttingen, Germany.

A small sample piece was embedded in epoxy resin and a thin section was prepared for petrographic investigation (Fig. 2B). To determine semi-quantitative, the mineralogical composition X-ray diffraction (XRD) analysis was performed. A few grams were taken from the bulk sample and a rock powder was produced using an agate ball mill. The analysis was conducted using a Philips X'Pert MPD, equipped with a PW3050 Goniometer, and CuKaradiation. The respective $\mathrm{X}$-ray diffractograms were compared to an internationally valid 
database using the X'Pert Data software package. All minerals with modal contents $>1 \%$ were identified until all the peaks were assigned. Peak interferences of diffractograms were considered during data evaluation. Sample preparation and illite crystallinity measurements on air-dried samples were conducted as outlined in Koehl et al. (2018). Illite crystallinity is expressed as the Kübler index $\left(\mathrm{KI}, \Delta^{\circ} 2 \theta\right)$, with the limits for diagenesis/anchizone (approximately $200^{\circ} \mathrm{C}$ ) and anchizone/epizone (approximately $300^{\circ} \mathrm{C}$ ) being 0.420 and 0.250 $\Delta^{\circ} 2 \theta$ (Kübler, 1967, 1968, 1984; Kisch et al. 2004), respectively.

Fine-fraction $\mathrm{K}-\mathrm{Ar}$ dating has been used in a number of studies producing reliable age constraints on low-grade metamorphism (e.g. Wemmer et al. 2011; Koehl et al. 2018). That technique was therefore also used in this study. The remaining about $2 \mathrm{~kg}$ of sample material was washed and dried and then crushed and ground in a shatter mill for 13-18 seconds until no graininess was registered by manual examination (Reuter 1985). The grain size fraction of $<2 \mu \mathrm{m}$ was gained by differential settling (Atterberg method) of the sieve fraction $<63 \mu \mathrm{m}$. Enrichment of the grain size fraction $<0.2 \mu \mathrm{m}$ was carried out by ultracentrifugation (Wemmer 1991). The Ar isotopic composition was measured in a Pyrex glass extraction and purification line coupled to a Thermo Scientific ${ }^{\mathrm{TM}}$ ARGUS VI ${ }^{\mathrm{TM}}$ noble gas mass spectrometer, operating in static mode, following the method outlined in Wemmer et al. (2011). The amount of radiogenic ${ }^{40} \mathrm{Ar}$ was determined by isotope dilution method using a highly enriched ${ }^{38} \mathrm{Ar}$ spike from Schumacher, Bern (Schumacher 1975). The spike was calibrated against the biotite standard HD-B1 (Fuhrmann et al. 1987). The age calculations are based on the constants recommended by the IUGS quoted in Steiger \& Jäger (1977). Potassium content was determined in duplicate by flame photometry using a BWB-XP. The samples were dissolved in a mixture of $\mathrm{HF}$ and $\mathrm{HNO}_{3}$. $\mathrm{CsCl}$ and $\mathrm{LiCl}$ were added as an ionisation buffer and internal standard, respectively. The analytical error for the $\mathrm{K}-\mathrm{Ar}$ age calculations is given at a $95 \%$ confidence level $(2 \sigma)$.

\section{Results}

According to the semi-quantitative XRD analysis, shale sample D14-G7 from the upper Ediacaran Indreelva Member consists of $71 \%$ phyllosilicates (mainly illite), 18\% quartz, 10\% feldspar (albite), and 1\% other mineral phases.

The $<2 \mu \mathrm{m}$ and $<0.2 \mu \mathrm{m}$ grain-size fractions are almost purely illite, with very minor chlorite and quartz, and yielded KI values of $0.215 \Delta^{\circ} 2 \theta$ and $0.228 \Delta^{\circ} 2 \theta$ (see Supplementary 
material). In both fractions, no traces of smectite or illite/smectite probably indicating a lowtemperature reactivation, could be detected.

Analytical results of the $\mathrm{K}-\mathrm{Ar}$ dating are presented in Table 1 . The $<2 \mu \mathrm{m}$ and $<0.2$ $\mu \mathrm{m}$ grain-size fractions yielded $\mathrm{K}-\mathrm{Ar}$ ages of $403.9 \pm 4.2 \mathrm{Ma}$ and $391.5 \pm 4.0 \mathrm{Ma}$, respectively, which is late Early to early Mid-Devonian (Emsian to early Eifelian), according to the International Chronostratigraphic Chart (Cohen et al. 2018).

\section{Discussion and conclusions}

To discuss the reliability of the obtained $\mathrm{K}-\mathrm{Ar}$ ages the following considerations need to be made. The $\mathrm{K}-\mathrm{Ar}$ dating technique relies on the assumption of closed-system behaviour so that neither loss nor gain of ${ }^{40} \mathrm{Ar}$ or ${ }^{40} \mathrm{~K}$ has occurred since illite formation. The $\mathrm{K}$-Ar closure temperature (temperature below which diffusion of ${ }^{40} \mathrm{Ar}$ is negligible) for illite fine fractions is poorly constrained to date. Hunziker et al. (1986) report a closure temperature for white mica fractions (sericite $<2 \mu \mathrm{m}$ ) in the order of $260 \pm 30^{\circ} \mathrm{C}$. Wemmer \& Ahrendt (1997) suggest that fine-grained white micas (sericite $<2 \mu \mathrm{m}$ ) do not behave as an open system, even at temperatures of $275^{\circ} \mathrm{C}$. Purdy \& Jäger (1976) constrained the upper limit of the $\mathrm{K}-\mathrm{Ar}$ closure temperature for white mica to around $350^{\circ} \mathrm{C}$.

According to the colour of the organic-walled microfossils from the Manndrapselva Member of the Stáhpogieddi Formation, the sedimentary rocks show a post-mature level, indicating a thermal overprint of 200 to $250^{\circ} \mathrm{C}$ (T. Palacios, unpublished data). This is near the lowermost limit for the $\mathrm{K}-\mathrm{Ar}$ closure temperature of fine-grained white mica. The illite crystallinity of the $<2 \mu \mathrm{m}$ and $<0.2 \mu \mathrm{m}$ grain-size fractions from the studied localised shear zone is $0.215 \Delta^{\circ} 2 \theta$ and $0.228 \Delta^{\circ} 2 \theta$, respectively, suggesting low epizonal metamorphic conditions of about $300^{\circ} \mathrm{C}$. Thus, the thermal overprint along the localised shear zone was at least $50-100^{\circ} \mathrm{C}$ higher than in the surrounding host sedimentary succession, if the different temperature proxies can be compared directly.

The obtained $\mathrm{K}-\mathrm{Ar}$ ages of $403.9 \pm 4.2 \mathrm{Ma}$ and $391.5 \pm 4.0 \mathrm{Ma}$ indicate the time of illite formation or cooling shortly after the temperature peak, and are therefore interpreted to represent the latest tectono-metamorphic event, which affected the sedimentary rocks on the Digermulen Peninsula.

A previous $\mathrm{K}-\mathrm{Ar}$ age of $440.2 \pm 9.4 \mathrm{Ma}(<0.5 \mu \mathrm{m}$ size fraction of illite $)$ from the southwestern part of the Gaissa Nappe Complex was interpreted as a maximum date for the cleavage formation (Dallmeyer et al. 1989). In addition, Dallmeyer et al. (1989) rejected ideas 
of the existence of an Early Ordovician (Finnmarkian) tectono-thermal imprint on the rock formations of the Gaissa Nappe Complex (cf. Sundvoll \& Roberts 2003). If peakmetamorphism in the Gaissa Nappe Complex is of early Silurian age (Dallmeyer et al. 1989) and has also affected the Digermulen Peninsula succession, but Silurian K-Ar ages are not recorded in the sample analysed in this study, we can conclude that the age of peakmetamorphism is either wrong or the temperature during peak-metamorphism was slightly lower than during the latest tectono-metamorphic event in Mid-Devonian time.

Gorokhov et al. (2001) presented finer illite fraction $\mathrm{Rb}-\mathrm{Sr}$ ages of $440 \mathrm{Ma}$ to $390 \mathrm{Ma}$ from shales of the Nyborg Formation and the Indreelva Member of the parautochthonous units on the Varanger Peninsula, which they related to Scandian deformation. In their smaller than $0.1 \mu \mathrm{m}$ size fraction, they obtained an age of $388 \pm 6$ Ma from the Nyborg Formation, which overlaps in error the younger age from the Indreelva Member of this study. They reported an age of $430 \pm 11 \mathrm{Ma}$ from the less than $0.1 \mu \mathrm{m}$ size fraction from the Indreelva Member, which is within the age range discussed by Dallmeyer et al. (1989) for the timing of peak-metamorphism of the Gaissa Nappe Complex. Although the $\mathrm{Rb}-\mathrm{Sr}$ ages by Gorokhov et al. (2001) are not derived from the Gaissa Nappe Complex but rather the parautochthonous units to the east, overall the data reveal prominent tectono-thermal events, one during the early Silurian (c. 430-440 Ma) and another in the late Early to Mid-Devonian (c. 388-400 $\mathrm{Ma})$.

One sample of ultracataclasite from the sole thrust of the Gaissa Nappe Complex (c. $12 \mathrm{~km}$ ENE of Lakselv) gave a K-Ar whole-rock age of $391 \pm 9 \mathrm{Ma}$ (J. G. Mitchell in Roberts \& Sundvoll 1990). This is intriguingly similar within 2-sigma error to the ages obtained in this study. The age is comparable to geochronological dates obtained from top-ESE shear bands affecting mylonites at the base of the Kalak Nappe Complex (Sundvoll \& Roberts 2003). Field evidence from basal parts of the Gaissa Nappe Complex shows that thrusting post-dated the peak of metamorphism and cleavage formation (Sundvoll \& Roberts 2003).

In summary, the fine-fraction $\mathrm{K}-\mathrm{Ar}$ ages of $403.9 \pm 4.2 \mathrm{Ma}$ and $391.5 \pm 4.0 \mathrm{Ma}$ reported for the first time from the Digermulen Peninsula in this study are interpreted to present late-stage thermal overprint along a localised shear zone, likely post-dating the peak of metamorphism and cleavage formation. Our study therefore confirms previous inferences (Roberts \& Sundvoll 1990) that a later tectono-metamorphic event related to the late stage of the Scandian orogeny is locally also recorded in the Gaissa Nappe Complex of the Caledonides of Finnmark. Taking into account Roberts \& Sundvoll (1990), Sundvoll \& Roberts (2003) and the new data presented here, this late Scandian event was probably caused 
by east-directed movements due to orogenic extensional collapse in the aftermath of the continent-continent collision between Laurentia and Baltica (e.g. Anderson et al. 1992; Andersen 1998) (Fig. 1D), and appears to have extended at least into Mid-Devonian time.

\section{Acknowledgements}

In the framework of the Digermulen Early Life Research Group financial support for fieldwork in Arctic Norway was provided by the Research Council of Norway (Grant No. 231103). Sören Jensen acknowledges funding from project CGL 2017-87631-P from Spanish MINECO. We thank Volker Karius and Annika Steichert for XRD analysis. Finally, we are grateful to Torgeir Bjørge Andersen and David G. Gee for constructive reviews.

\section{Disclosure statement}

No potential conflict of interest was reported by the authors.

\section{Supplementary material}

Supplemental material for this article is available via the supplemental tab on the article's online page at http://xxxxx

\section{References}

Andersen, T.B., 1998: Extensional tectonics in the Caledonides of southern Norway, an overview. Tectonophysics 285, 333-351.

Anderson, M.W., Barker, A.J., Bennett, D.G. \& Dallmeyer, R.D., 1992: A tectonic model for the Scandian terrane accretion in the northern Scandinavian Caledonides. Journal of the Geological Society, London 149, 727-741.

Banks, N.L., Edwards, M.B., Geddes, W.P., Hobday, D.K. \& Reading, H.G., 1971: Late Precambrian and Cambro-Ordovician sedimentation in East Finnmark. Norges Geologiske Undersøkelse 269, 197-236.

Cohen, K.M., Harper, D.A.T., Gibbard, P.L. \& Fan, J.-X., 2018: International Chronostratigraphic Chart 2018/08. International Commission on Stratigraphy. http://www.stratigraphy.org/ICSchart/ChronostratChart2018-08.pdf 
Corfu, F., Gerber, M., Andersen, T.B., Torsvik, T.H. \& Ashwal, L.D., 2011: Age and significance of Grenvillian and Silurian orogenic events in the Finnmarkian Caledonides, northern Norway. Canadian Journal of Earth Sciences 48, 419-440.

Corfu, F., Andersen, T.B. \& Gasser, D., 2014: The Scandinavian Caledonides: main features, conceptual advances and critical questions. In F. Corfu, D. Gasser \& D.M. Chew (eds.): New perspectives on the Caledonides of Scandinavia and related areas. Geological Society London, Special Publications 390, 9-43.

Dallmeyer, R.D., 1988: Polyphase tectonothermal evolution of the Scandinavian Caledonides. In A.L. Harris \& D.J. Fettes (eds.): The Caledonian-Appalachian orogen. Geological Society London, Special Publications 38, 365-379.

Dallmeyer, R.D., Reuter, A., Clauer, N. \& Leiwig, N., 1989: Chronology of Caledonian tectonothermal activity within the Gaissa and Laksefjord Nappe Complexes (Lower Allochthon), Finnmark, Norway: Evidence from $\mathrm{K}-\mathrm{Ar}$ and ${ }^{40} \mathrm{Ar} /{ }^{39} \mathrm{Ar}$ ages. In R.A. Gayer (ed.): The Caledonide geology of Scandinavia. Graham \& Trotman, London, 9-26.

Farmer, J., Vidal, G., Moczydłowska, M., Strauss, H., Ahlberg, P. \& Siedlecka, A., 1992: Ediacaran fossils from the Innerelv Member (late Proterozoic) of the Tanafjorden area, northeastern Finnmark. Geological Magazine 129, 181-195.

Fuhrmann, U., Lippolt, H.J. \& Hess, J.C., 1987: Examination of some proposed K-Ar standards: ${ }^{40} \mathrm{Ar} /{ }^{39} \mathrm{Ar}$ analyses and conventional K-Ar data. Chemical Geology 66, 41-51.

Gayer, R.A., Rice, A.H.N., Roberts, D., Townsend, C. \& Welbon, A.I.F., 1987: Restoration of the Caledonian Baltoscandian margin from balanced cross-sections: the problem of excess continental crust. Transactions of the Royal Society of Edinburgh: Earth Sciences $78,197-217$.

Gee, D.G., Kumpulainen, R., Roberts, D., Stephens, M.B., Thon, A. \& Zachrisson, E., 1985:

Scandinavian Caledonides tectonostratigraphic map, scale 1:2,000,000. Sveriges Geologiska Undersökning Ba 35.

Gorokhov, I.M., Siedlecka, A., Roberts, D., Melnikov, N.M. \& Turchenko, T.L., 2001: Rb-Sr dating of diagenetic illite in Neoproterozoic shales, Varanger Peninsula, northern Norway. Geological Magazine 138, 541-562.

Högström, A.E.S., Jensen, S., Palacios, T. \& Ebbestad, J.O.R., 2013: New information on the Ediacaran-Cambrian transition in the Vestertana Group, Finnmark, northern Norway, from trace fossils and organic-walled microfossils. Norwegian Journal of Geology 93, 95-106. 
Högström, A.E.S., Jensen, S., Ebbestad, J.O.R., Taylor, W.L., Høyberget, M., Agić, H., Meinhold, G. \& Palacios, T., 2017: Expanding the Ediacaran biota on the Digermulen Peninsula, Arctic Norway. In D. McIlroy (ed.): ISECT 2017-International Symposium on the Ediacaran-Cambrian transition. Abstract Volume, p. 45.

Hunziker, J.C., Frey, M., Clauer, N., Dallmeyer, R.D., Friedrichsen, H., Flehmig, W., Hochstrasser, K., Roggwiler, P. \& Schwander, H., 1986: The evolution of illite to muscovite: Mineralogical and isotopic data from the Glarus Alps, Switzerland: Contributions to Mineralogy and Petrology 92, 157-180.

Jensen, S., Högström, A.S., Almond, J., Taylor, W.L., Meinhold, G., Høyberget, M., Ebbestad, J.O.R., Agić, H. \& Palacios, T., 2018a: Scratch circles from the Ediacaran and Cambrian of Arctic Norway and the Republic of South Africa, with a review of scratch circle occurrences. Bulletin of Geosciences 93, 287-304.

Jensen, S., Högström, A.E.S., Høyberget, M., Meinhold, G., McIlroy, D., Ebbestad, J.O.R., Taylor, W.L., Agić, H. \& Palacios, T., 2018b: New occurrences of Palaeopascichnus from the Stáhpogieddi Formation, Arctic Norway, and their bearing on the age of the Varanger Ice Age. Canadian Journal of Earth Sciences 55, 1253-1261.

Kirkland, C.L., Daly, J.S., Chew, D.M. \& Page, L., 2008: The Finnmarkian Orogeny revisited: an isotopic investigation in eastern Finnmark, Arctic Norway. Tectonophysics 460, 158-177.

Kisch, H.J., Árkai, P. \& Brime, C., 2004: On the calibration of the illite Kübler index (illite “crystallinity"). Schweizerische Mineralogische und Petrographische Mitteilungen 84, $323-331$.

Koehl, J.-B.P., Bergh, S.G. \& Wemmer, K., 2018: Neoproterozoic and post-Caledonian exhumation and shallow faulting in NW Finnmark from $\mathrm{K}-\mathrm{Ar}$ dating and $p / T$ analysis of fault rocks. Solid Earth 9, 923-951.

Kübler, B., 1967: La cristallinité de l'illite et les zones tout à fait supérieures du métamorphisme. In Schaer, J.-P. (ed.): Etages tectoniques: Colloque de Neuchâtel, 18-21 avril 1966. A la Baconnière, Neuchâtel, 105-121.

Kübler, B., 1968: Evaluation quantitative du métamorphisme par la cristallinité de l'illite. Bulletin de la Centre Recherche de Pau - S.N.P.A. 2, 385-397.

Kübler, B., 1984: Les indicateurs des transformations physiques et chimiques dans la diagenèse, température et calorimétrie. In M. Lagache (ed.): Thermobarométrie et Barométrie Géologiques. Societe de Francais Minéalogie et Cristallographie, Paris, 489596. 
Pringle, I.R., 1973: Rb-Sr age determinations on shales associated with the Varanger ice age. Geological Magazine 109, 465-172.

Purdy, J.W. \& Jäger, E., 1976: K-Ar ages on rock-forming minerals from the Central Alps. Memorie Instituto Geologia Mineralogia Universita Padova 30, 1-31.

Reading, H.G., 1965: Eocambrian and Lower Palaeozoic geology of the Digermul Peninsula, Tanafjord, Finnmark. Norges Geologiske Undersøkelse 234, 167-191.

Reuter, A., 1985: Korngrößenabhängigkeit von K-Ar Datierung und Illit-Kristalinität anchizonaler Metapelite und assoziierter Metatuffe aus dem östlichen Rheinischen Schiefergebirge. Göttinger Arbeiten zur Geologie und Paläontologie 27, 1-91.

Rice, A.H.N., 2014: Restoration of the external Caledonides, Finnmark, North Norway. In F. Corfu, D. Gasser \& D.M. Chew (eds.): New Perspectives on the Caledonides of Scandinavia and related areas. Geological Society of London, Special Publications 390, 271-299.

Roberts, D., 1985: The Caledonian fold belt in Finnmark: a synopsis. Norges Geologiske Undersøkelse Bulletin 403, 161-177.

Roberts, D. \& Sundvoll, B., 1990: Rb-Sr whole-rock and thin-slab dating of mylonites from the Kalak Thrust Zone, near Børselv, Finnmark. Norsk Geologisk Tidsskrift 70, 259-266.

Rosendahl, H., 1945: Prekambrium-Eokambrium i Finnmark. Norsk Geologisk Tidsskrift 25, 327-349.

Schumacher, E., 1975: Herstellung von 99.9997\% ${ }^{38} \mathrm{Ar}$ für die ${ }^{40} \mathrm{~K} /{ }^{40} \mathrm{Ar}$ Geochronologie. Geochronologia Chimia 24, 441-442

Scotese, C.R., 2016: PALEOMAP PaleoAtlas for GPlates and the PaleoData Plotter Program, PALEOMAP Project, http://www.earthbyte.org/paleomap-paleoatlas-for-gplates/

Siedlecka, A., Reading, H.G., Williams, G.D. \& Roberts, D., 2006: Langfjorden, preliminary bedrock geology map 2236 II, scale 1:50.000. Norges Geologiske Undersøkelse, Trondheim.

Steiger, R.H. \& Jäger, E., 1977: Subcommission on Geochronology: convention on the use of decay constants in Geo- and Cosmochronology. Earth and Planetary Science Letters 36, 359-362.

Sturt, B.A., Pringle, I.R. \& Roberts, D., 1975: Caledonian nappe sequence of Finnmark, northern Norway and the timing of orogenic deformation and metamorphism. Geological Society of America Bulletin 86, 710-718.

Sturt, B.A., Pringle, I.R. \& Ramsay, D.M., 1978: The Finnmarkian phase of the Caledonian Orogeny. Journal of the Geological Society, London 135, 597-610. 
Sundvoll, B. \& Roberts, D., 2003: A likely Early Ordovician age for the regional, penetrative cleavage in the Gaissa Nappe Complex, northern Norway. Norges Geologiske Undersøkelse Bulletin 441, 51-59.

Townsend, C., Roberts, D., Rice, A.H.N. \& Gayer, R.A., 1986: The Gaissa Nappe, Finnmark, North Norway: an example of a deeply eroded external imbricate zone within the Scandinavian Caledonides. Journal of Structural Geology 8, 431-440.

Wemmer, K., 1991: K/Ar-Altersdatierungsmöglichkeiten für retrograde Deformationsprozesse im spröden und duktilen Bereich—Beispiele aus der KTBVorbohrung (Oberpfalz) und dem Bereich der Insubrischen Linie (N-Italien). Göttinger Arbeiten zur Geologie und Paläontologie 51, 1-61.

Wemmer, K. \& Ahrendt, H., 1997: Comparative K-Ar and Rb-Sr age determinations of retrograde processes on rocks from the KTB deep drilling project. Geologische Rundschau 86(S1), S272-S285.

Wemmer, K., Steenken, A., Müller, S., de Luchi, M.G.L. \& Siegesmund, S., 2011: The tectonic significance of K/Ar illite fine-fraction ages from the San Luis Formation (Eastern Sierras Pampeanas, Argentina). International Journal of Earth Sciences 100, 659-669. 


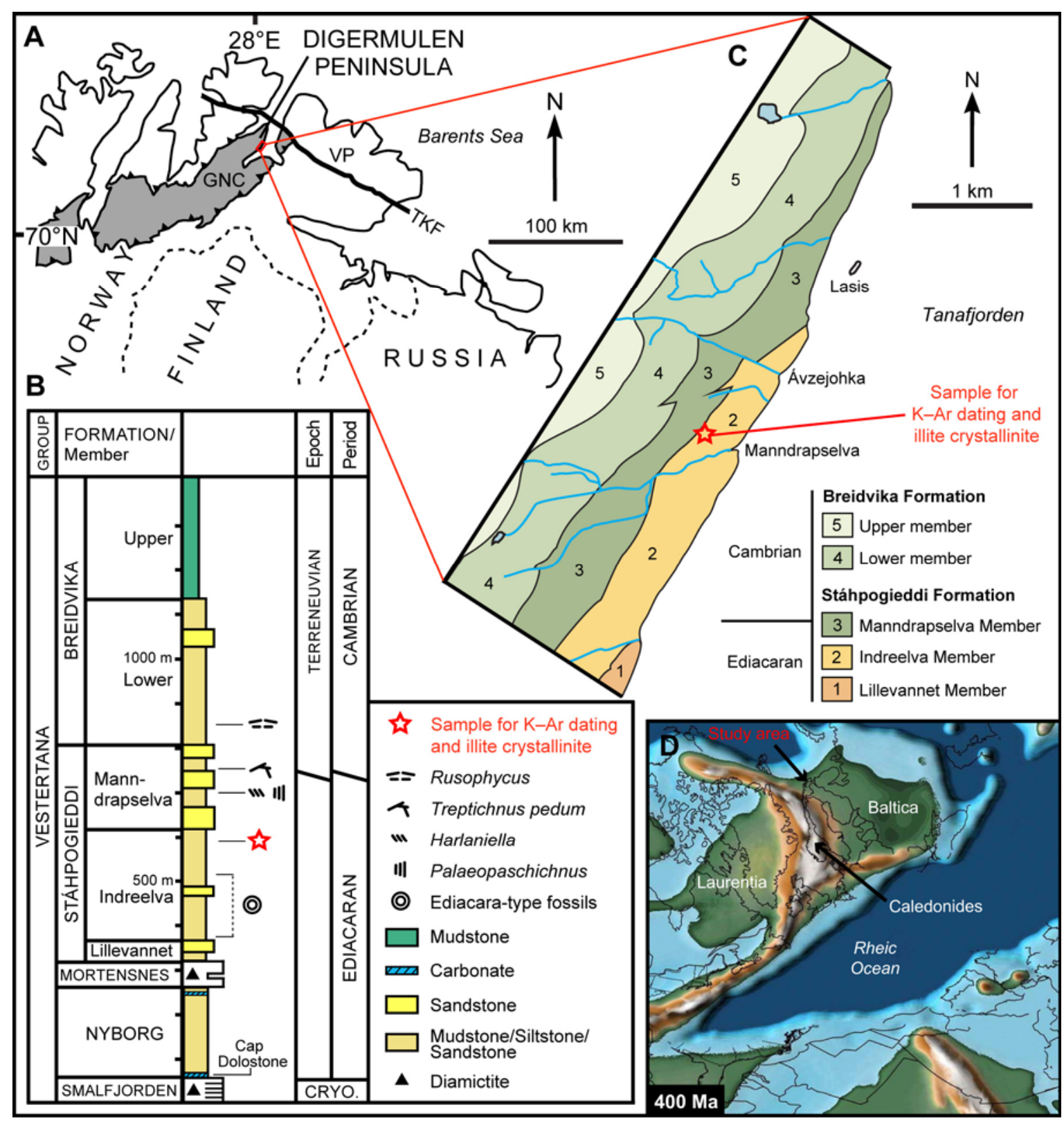

Figure 1. A. Outline of northernmost Scandinavia showing the Vestertana Group rocks, in grey shade, preserved within the Gaissa Nappe Complex (GNC) and para-autochthonous in eastern Finnmark on the Varanger Peninsula (VP). Red box marks study area. TKF -

Trollfjorden-Komagelva Fault Zone. B. Simplified stratigraphy of the Vestertana Group (after Jensen et al., 2018b), showing stratigraphic position of the shale sample used for finefraction K-Ar dating (this study). C. Geology of the south-east portion of the Digermulen Peninsula, based on Siedlecka et al. (2006), showing locality where sample for fine-fraction $\mathrm{K}-\mathrm{Ar}$ dating was taken in the field (see text for details). D. Emsian (400 Ma) palaeogeographic reconstruction showing Caledonian mountain belt between Baltica and Laurentia (after Scotese, 2016). 

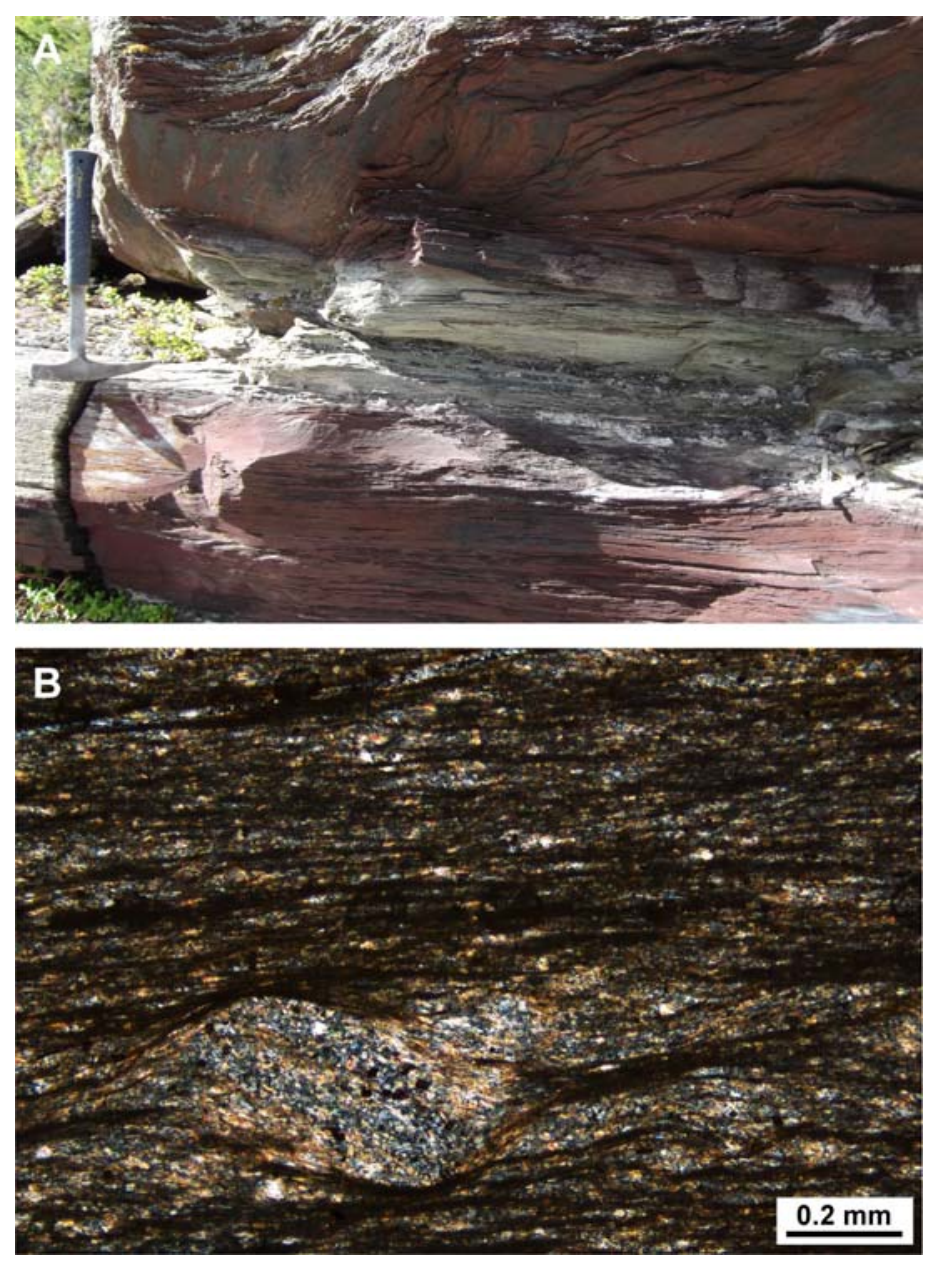

Figure 2. A. Field photograph showing pale olive green shale sandwiched between red-brown shale of the upper Indreelva Member. Hammer length is $30 \mathrm{~cm}$. B. Thin-section photomicrograph of the pale olive green shale (sample D14-G7, cut perpendicular to bedding) showing abundant phyllosilicates and very fine quartz and feldspar grains, in crossed nicols. Asymmetric sigma-shape developed under low-grade metamorphic conditions indicates shearing. No statement about the sense of shear (kinematics) can be made, as the sample was not taken orientated. A colour version of this figure is available in the online version. 
Table 1. Results of the $\mathrm{K}-\mathrm{Ar}$ dating.

\begin{tabular}{|l|c|c|c|c|c|c|}
\hline Sample & $\begin{array}{c}\text { Size fraction } \\
(\boldsymbol{\mu m})\end{array}$ & $\begin{array}{c}\mathbf{K}_{\mathbf{2}} \mathbf{O} \\
(\mathbf{w t} . \%)\end{array}$ & $\begin{array}{c}{ }^{40} \mathbf{A r}^{*} \\
(\mathbf{n L} / \mathbf{g}) \mathbf{S T P}\end{array}$ & $\begin{array}{c}{ }^{40} \mathbf{A r}^{*} \\
(\mathbf{\%})\end{array}$ & $\begin{array}{c}\text { Age } \\
(\mathbf{M a})\end{array}$ & $\begin{array}{c}\mathbf{\pm 2 \sigma} \text {-error } \\
(\mathbf{M a})\end{array}$ \\
\hline D14-G7 & $<2$ & 8.83 & 128.98 & 99.77 & 403.9 & 4.2 \\
\hline D14-G7 & $<0.2$ & 9.17 & 129.33 & 99.24 & 391.5 & 4.0 \\
\hline
\end{tabular}

Note: ${ }^{40} \mathrm{Ar}{ }^{*}$-radiogenic argon; STP—standard pressure and temperature conditions 
Supplementary material of the GFF article

\section{A late Caledonian tectono-thermal event in the Gaissa Nappe Complex, Arctic Norway: evidence from fine-fraction K-Ar dating and illite crystallinity from the Digermulen Peninsula}

Guido Meinhold $^{\mathrm{a}, \mathrm{b}}$, Klaus Wemmer ${ }^{\mathrm{b}}$, Anette E. S. Högström ${ }^{\mathrm{c}}$, Jan Ove R. Ebbestad ${ }^{\mathrm{d}}$, Sören Jensen $^{\mathrm{e}}$, Teodoro Palacios ${ }^{\mathrm{e}}$, Magne Høyberget ${ }^{\mathrm{f}}$, Heda Agić ${ }^{\mathrm{g}}$ and Wendy L. Taylor ${ }^{\mathrm{h}}$

${ }^{\mathrm{a} S}$ School of Geography Geology and the Environment, Keele University, Keele, UK;

${ }^{\mathrm{b}}$ Geowissenschaftliches Zentrum Göttingen, Universität Göttingen, Göttingen, Germany;

${ }^{\mathrm{c}}$ Tromsø University Museum, UiT - The Arctic University of Norway, Tromsø, Norway;

${ }^{\mathrm{d}}$ Museum of Evolution, Uppsala University, Uppsala, Sweden;

'Área de Paleontología, Universidad de Extremadura, Badajoz, Spain;

${ }^{\mathrm{f}}$ Rennesveien 14, Mandal, Norway;

${ }^{g}$ Department of Earth Science, University of California, Santa Barbara, USA;

${ }^{\mathrm{h}}$ Department of Geological Sciences, University of Cape Town, Rondebosch, South Africa

Table S1. Results of illite crystallinite (Kübler index, KI, $\Delta^{\circ} 2 \theta$ ) determination.

\begin{tabular}{|c|c|c|c|c|c|c|}
\hline Sample & $\begin{array}{c}\text { Size fraction } \\
(\boldsymbol{\mu m})\end{array}$ & Specimen & Condition & counts/sec & $\Delta^{\circ} \mathbf{2 \Theta}$ & $\boldsymbol{\phi} \Delta^{\circ} \mathbf{2} \Theta$ \\
\cline { 1 - 6 } D14-G7 & $<2$ & A & Air dry & 5892 & 0.218 & \\
\hline D14-G7 & $<2$ & B & Air dry & 4214 & 0.211 & $\mathbf{0 . 2 1 5}$ \\
\hline D14-G7 & $<0.2$ & A & Air dry & 3816 & 0.228 & \\
\hline D14-G7 & $<0.2$ & B & Air dry & 4023 & 0.228 & $\mathbf{0 . 2 2 8}$ \\
\hline
\end{tabular}

